\title{
Analysis of Using Online Learning Media Via Whatsapp During The Covid-19 Pandemic At Smp Negeri 8 City of Bengkulu
}

\author{
Lensi Herlina \\ Tadris IPA, Fakultas FTT, IAIN Bengkulu, lensiherlina3@gmail.com \\ Monika Dwi Anggita \\ Tadris IPA, Fakultas FTT, IAIN Bengkulu, monikadwianggita@gmail.com \\ Sisi Mulia Utami \\ Tadris IPA, Fakultas FTT, IAIN Bengkulu, sisiutami2001@gamail.com \\ Ahmad Walid \\ Tadris IPA, Fakultas FTT, IAIN Bengkulu, ahmadwalid@iainbengkulu.ac.id
}

\begin{abstract}
The learning process during the COVID-19 pandemic must be carried out online. The use of media in learning becomes very important. This study aims to describe the effectiveness of using the WhatsApp application as a learning medium during the COVID-19 pandemic. The research subjects here are eighth grade students of SMP Negeri 8 Bengkulu City. This type of research is descriptive quantitative research. Data collection techniques in this study were carried out in the form of a questionnaire. The results obtained are that the use of WhatsApp as an online learning medium during the Covid-19 pandemic can be said to be quite effective with a score of $59.6 \%$ based on filling out a questionnaire by 15 class VIII students at SMP Negeri 8 Bengkulu City in achieving the goal. learning.
\end{abstract}

Keywords: effectiveness, learning media, WhatsApp.

\section{INTRODUCTION}

The COVID-19 pandemic has had an impact on almost all aspects of life, for example the economy, religion, social, environment, including education. The United Nations Educational, Scientific and Cultural Organization (UNESCO), an organization under the United Nations in charge of education, science, and culture on Thursday (5/3/2020) stated that the Covid-19 outbreak had a very serious impact on the education sector. Nearly 300 million students worldwide are affected by their school activities and threaten their educational rights in the future (Gumono \& Yulistio, 2021). The world of education in Indonesia is also not spared from this impact. If this pandemic condition is not under control, then the education sector will almost certainly be worse off. The most obvious impact is that students at all levels and types of education cannot carry out face-to-face learning.
With this pandemic, many changes have occurred in education in Indonesia, such as changes in learning patterns, from direct learning to online learning (DARING). The activities of students and teachers at schools are strictly limited with the aim of breaking the chain of transmission of COVID-19. In general, during this pandemic all learning activities are carried out from home. Because of this, teachers are required to try to provide teaching to students as much as possible even with learning from home. Many teachers experience limitations in the learning media that will be used during online learning.

Media can be used as a means to convey information, especially to facilitate the thinking process of students. These media include visualbased media, visualization of messages, information, or concepts to be conveyed to students. This can take the form of: a graph, Photo, mechanical tools, electronic tools used to obtain, process, and convey information 
(Rosyid, 2019). According to (Novita et al., 2019) suggests that the use of learning media in the teaching and learning process can generate desire and interest, generate motivation and stimulation in learning activities, and can bring psychological effects on students. The use of learning media in the learning process can also help students improve their understanding, present data in an interesting and reliable way, facilitate data interpretation, and conclude information.(Irawan \& Ermawaty, 2020)

The use of WhatsApp as a learning medium occurs a lot at the junior high school level. Of course, for various reasons. At the higher education level, WhatsApp is only one medium. In contrast to junior high schools, from a survey conducted by researchers, $100 \%$ of online learning only uses WhatsApp. Interesting and important to examine how effective online learning through WhatsApp is. (Daheri et al., 2020)

\section{METHODS}

The type of research used is descriptive quantitative research. Because this study aims to describe the effectiveness of using the WhatsApp application as a learning medium during the COVID-19 pandemic. The population in this study were grade VIII students at SMP Negeri 8 Bengkulu City. The data collection technique in this research is a questionnaire. The use of questionnaires through the assistance of students of SMP Negeri 8 Bengkulu City. Questionnaire is a non-test instrument in the form of a list of questions that must be answered by the person who is the subject of the research. Meanwhile, data analysis was carried out using descriptive analysis assisted by an Excel application on a computer.(Suriyanto et al., 2021)

\section{RESULTS AND DISCUSSION Result}

Based on the results obtained during the research at SMP NEGERI 8 Bengkulu City, class VIII, we got results about the effectiveness of using WhatsApp learning media while ONLINE from filling out questionnaires by 15 students as follows:

Table 1. Results About The Effectiveness Of Using Whatsapp Learning Media While ONLINE

\begin{tabular}{lcccccc}
\hline RESPONDEN & SS & S & RR & TS & STS & $\begin{array}{c}\text { RATA- } \\
\text { RATA }\end{array}$ \\
\hline Agustin & 4 & 2 & 9 & 5 & 0 & 4 \\
\hline Meylinda & 4 & 2 & 9 & 5 & 0 & 4 \\
\hline keyla & 6 & 2 & 8 & 2 & 1 & 3.8 \\
\hline bunga & 3 & 10 & 3 & 4 & 0 & 4 \\
\hline Kayla & 0 & 14 & 5 & 1 & 0 & 4 \\
\hline Fajri & 11 & 2 & 3 & 1 & 3 & 4 \\
\hline Riski & 3 & 5 & 2 & 5 & 5 & 4 \\
\hline Agustian & 4 & 2 & 9 & 4 & 0 & 3.8 \\
\hline Arga & 5 & 1 & 10 & 4 & 0 & 4 \\
\hline Juwita & 2 & 8 & 9 & 1 & 0 & 4 \\
\hline Chelsy & 4 & 2 & 9 & 5 & 0 & 4 \\
\hline Farizi & 4 & 2 & 9 & 5 & 0 & 4 \\
\hline Jumeidi & 13 & 1 & 3 & 2 & 1 & 4 \\
\hline Engel & 2 & 6 & 9 & 3 & 0 & 4 \\
\hline Keyza & 2 & 6 & 3 & 6 & 3 & 4 \\
\hline JUMLAH & 67 & 65 & 100 & 53 & 13 & 59.6 \\
\hline
\end{tabular}

So with the criteria for interpreting the score based on the interval:

$>$ Number $0 \%-19.9 \%=$ Strongly disagree $/$ bad / very less.

$>$ Numbers $20 \%-39.9 \%=$ Disagree/not good

$>$ Numbers $40 \%-59.9 \%=$ Enough $/$ Neutral

$>$ Numbers $60 \%-69.9 \%=$ Agree/good/like

$>$ Score $80 \%-100 \%=$ Strongly agree/very good/very like

$$
\begin{aligned}
& \text { Total score }=298 \\
& \text { So } \frac{\text { Total score }}{y \times 100}=\frac{298}{500}=59,6 \times 100 \% \\
& =59,6 \%
\end{aligned}
$$

With a value of $59.6 \%$, it is in the "Enough" category. 


\section{Discussion}

The discussion in this study is about the effect of WhatsApp learning media on student learning processes while online (Covid-19) in class VIII at SMP Negeri 8 Bengkulu City. The research respondents were class VIII students, totaling 15 students. Learning that is carried out by utilizing information and communication technology depends on the role of the teacher as a facilitator not only as a provider of information, but also providing convenience in learning.

\section{Online Learning}

The existence of a virus that appeared suddenly that attacked almost all over the world, including Indonesia, made every human activity, whether economic, social or even educational, have a very significant impact. In education, all learning is done online. Online learning is a learning system that is carried out using pedagogical tools or educational aids that allows you to use internet access and good information technology to be a facility in the formation of the learning process and knowledge through interactions carried out. (Habibah et al., 2020)

\section{WhatsApp}

WhatsApp is one of the communication media that is familiar to our ears and is even very popular and is the platform that we use today for both personal and social interests. This application is almost owned by all gadget users. Besides being able to be used to communicate remotely, this platform can also be used as a supporting medium in the learning process, such as during the current pandemic. This platform is a tool used to carry out long-distance communication in the form of conversations using text, images, sound and video. WhatsApp is able to connect with our friends and family who are anywhere and anytime when we have a good network that is able to support us to access it. (Habibah et al., 2020)

From the results we got from the table through observations and interviews, 15 respondents (59.6\%) agreed about the effectiveness of using WhatsApp during online learning. The use of WhatsApp as an online learning medium during the Covid-19 pandemic can be said to be quite effective in achieving learning goals. This is in accordance with the statement of one of the teachers at SMP Negeri 8 Bengkulu City "I explain the learning materials with learning videos, pictures, and voice messages. In addition, the use of WhatsAPP saves internet quota compared to other media, such as zoom, Google Meet, and others.

As with the opinion expressed by (Yensy, 2020) that learning with WhatsApp media is quite effective "In accordance with the opinion expressed by (Munawaroh, 2019) that learning using WhatsApp media makes students more active in digging for information so that they try themselves to answer problems asked, especially in solving practice questions. Furthermore, Ricu Sidiq (2019) also stated the same thing that WhatsApp Group media can be used".

In the learning process the use of teaching media can help achieve learning success. According to AECT (Association of Education and Communication Technology) quoted by Basyaruddin (2002) "media are all forms used for the process of distributing information". Meanwhile, according to (Adam \& T.S, 2015) that learning media are everything both physical and technical in the learning process that can help teachers to make it easier to convey subject matter to students so as to facilitate the achievement of learning objectives that have been formulated. Furthermore (Joni Purwono, et al, 2014) explains that learning media has an important role in supporting the quality of the teaching and learning process. Media can also make learning more interesting and fun. One of the learning media that is currently developing is audiovisual media. (Irawan \& Ermawaty, 2020).

From the results above, it can be concluded that learning media is a tool in the teaching and learning process to stimulate the thoughts, 
feelings, attention and abilities or skills of the learner so that it can encourage the learning process. Types of Learning Media The very rapid development of education has an effect on the development of learning psychology as well as on the existing education system. This situation encourages and results in the advancement of learning technology and new additions to learning media. Along with technological advances, the development of learning media so fast, where each existing media has its own characteristics and abilities.

\section{CONCLUSION}

Based on the results of the study on "Analysis of the Use of Online Learning Media Using Via Whatsaap in the Covid-19 Pandemic Period at SMP Negeri 8 Bengkulu City", the researchers can draw the conclusion that the use of learning media via WhatsApp during the covid-19 pandemic is quite effective with a value of $59.6 \%$ based on filling out a questionnaire by 15 grade VIII students at SMP Negeri 8 Bengkulu City.

\section{REFERENCES}

Asnawir dan M. Basyiruddin Usman. (2002). Media Pembelajaran, Jakarta: Ciputat Pers.

Adam, S., \& T.S, M. (2015). Pemanfaatan Media Pembelajaran Berbasis Teknologi Informasi Bagi Siswa Kelas X SMA Ananda Batam. CBIS Journal, 3(2), 7890. https://ejournal.ap.fisipunmul.ac.id/site/wpcontent/uploads/2013/05/PRINT JURNAL SITI (05-09-13-03-29-59).pdf

Daheri, M., Juliana, J., Deriwanto, D., \& Amda, A. D. (2020). Efektifitas WhatsApp sebagai Media Belajar Daring. Jurnal Basicedu, 4(4), 775-783. https://doi.org/10.31004/basicedu.v4i4.44 5

Ekantini, A. (2020). Efektivitas Pembelajaran Daring pada Mata Pelajaran IPA di Masa Pandemi Covid-19: Studi Komparasi
Pembelajaran Luring dan Daring pada Mata Pelajaran IPA SMP. Jurnal Pendidikan Madrasah, 5(2), 187-194.

Gumono, G., \& Yulistio, D. (2021). Pengembangan Media Pembelajaran Daring bagi Guru Bahasa Indonesia SMP di Kabupaten Seluma Provinsi Bengkulu. Community Empowerment, 6(3), 444-455. https://doi.org/10.31603/ce.4455

Habibah, R., Salsabila, U. H., Lestari, W. M., Andaresta, O., \& Yulianingsih, D. (2020). Pemanfaatan Teknologi Media Pembelajaran di Masa Pandemi Covid-19. Trapsila: Jurnal Pendidikan Dasar, 2(02), 1. https://doi.org/10.30742/tpd.v2i2.1070

Irawan, V., \& Ermawaty, I. R. (2020). Analisis_kebutuhan_media_pembelajaran PROSIDING Seminar Nasional Pendidikan Fisika FITK UNSIQ 2020, 2(1), 1-6.

Munawaroh, I. (2019). Penggunaan Media Sosial Sebagai Upaya Meningkatkan Hasil Belajar Matematika Peserta Didik Kelas IX di SMP Negeri 1 Sindangkasih. Prosiding Seminar Nasional \& Call For Papers, 1(9), 266-273.

Novita, L., Sukmanasa, E., \& Pratama, M. Y. (2019). Penggunaan Media Pembelajaran Video terhadap Hasil Belajar Siswa SD. Indonesian Journal of Primary Education Penggunaan, 3(2), 64-72.

Rosyid, M. Z., Sa'diyah, H., \& Septiana, N. (2019). Ragam Media Pembelajaran. Malang: Literasi Nusantara.

Sadikin, A., \& Hamidah, A. (2020). Pembelajaran Daring Di Tengah Wabah Covid-19 (Online Learning in the Middle of the Covid-19 Pandemic). Biodik, 6(2), 214-224.

Suriyanto, B., Hidayat, T., Pristian, R., \& Astuti, F. (2021). Pengaruh Pembelajaran Daring Terhadap Hasil Belajar Siswa Pada Mata Pelajaran Ips Kelas Viii Di Smp Miftahul Falah Senori Tuban Tahun Ajaran 2020 / 2021. 1-7.

Purwono, J. (2014). Penggunaan media audiovisual pada mata pelajaran ilmu pengetahuan alam di Sekolah Menengah Pertama Negeri 1 Pacitan. Jurnal teknologi pendidikan dan pembelajaran, 2(2). 
Sidiq, R. (2019). Pemanfaatan Whatsapp Group dalam Pengimplementasian Nilai-Nilai Karakter Pancasila Pada Era Disrupsi. Puteri Hijau: Jurnal Pendidikan Sejarah, $4(2), 145-154$.

Yensy, N. A. (2020). Efektifitas Pembelajaran
Statistika Matematika melalui Media Whatsapp Group Ditinjau dari Hasil Belajar Mahasiswa (Masa Pandemik Covid 19). Jurnal Pendidikan Matematika Raflesia, 05(02), 65-74. https://ejournal.unib.ac.id/index.php/jpmr 